\title{
Evaluation of Environmental Impact on Heavy Metal Load in Cattle Milk
}

\author{
Rubina Parween $^{1 *}$, S. Shahid Shaukat ${ }^{2}$, Kousar Yasmeen ${ }^{1}$, Darakhshan Ara ${ }^{3}$ \\ ${ }^{1}$ Deparment of Chemistry, Federal Urdu University, Gulshan-e-Iqbal, \\ Karachi-75300, Pakistan \\ ${ }^{2}$ Institute of Environmental Studies, University of Karachi, Pakistan \\ ${ }^{3}$ Dawood Engineering University, Karachi, Pakistan
}

Received: 30 December 2015

Accepted: 2 January 2016

\begin{abstract}
The present work is designed to investigate the concentrations of heavy metals $(\mathrm{Cr}, \mathrm{Mn}, \mathrm{Fe}, \mathrm{Co}, \mathrm{Ni}, \mathrm{Cu}$, $\mathrm{Zn}, \mathrm{Cd}$, and $\mathrm{Pb}$ ) and physico-chemical properties including $\mathrm{pH}$, conductivity, salinity, total dissolved solid (TDS), dissolved oxygen (DO), and specific gravity that were analyzed in fresh bovine milk samples sold in various towns of District East, Karachi. Statistical techniques, including cluster analysis and principal component analysis (PCA), were performed to organize the recorded data in such a way as to expose the internal structure of multivariate data matrix. Results of PCA revealed that conductivity, salinity, and TDS possessed strong relationships with each other. The levels of heavy metals were assessed by atomic absorption spectroscopy (AAS). The mean concentrations of $\mathrm{Cr}, \mathrm{Mn}, \mathrm{Fe}, \mathrm{Co} \mathrm{Ni}, \mathrm{Cu}, \mathrm{Zn}, \mathrm{Cd}$, and $\mathrm{Pb}$ were assessed as 0.001-0.232 mg/l, 0.001-0.460 mg/1, 0.001-3.260 mg/1, 0.001-0.108 mg/1, 0.001-0.122 mg/l, 0.001-0.098 mg/l, 2.086-5.498 mg/1, 0.001-0.053 mg/l, and 0.001-1.428 mg/l, respectively. Remarkable numbers of samples were found to be contaminated with $\mathrm{Cd}$ and $\mathrm{Pb}$ and exceeded the tolerable guidelines set by standards.
\end{abstract}

Keywords: cattle milk, physico-chemical properties, heavy metals, CA, PCA

\section{Introduction}

Milk is a vital food for infants and imperative in diets for all age groups due to its extraordinarily nourishing ingredients in a balanced profile that are essential for health and growth. Although elements (minerals and heavy metals) are naturally present in milk and foodstuffs, they can come into milk and food as a result of anthropogenic pathways such as transport, industry, power generation,

*e-mail: r_perween1@yahoo.com and refuse burning [1]. Chemically, $\mathrm{Mg}, \mathrm{Fe}, \mathrm{Cu}, \mathrm{Zn}, \mathrm{Mn}$, and Mo are needed by enzymes as cofactors that are present in milk. Moreover, Fe and $\mathrm{Mn}$ are fractionally associated with lactoferrin (a bacteriostatic protein), whereas $\mathrm{Fe}$ is also linked with transferring xanthine oxidase and, slightly, casein; $\mathrm{Cu}$ is associated with caseins, $\beta$-lactoglobulin, lactoferrin, and some with milk fat membrane; $\mathrm{Zn}$ is associated with lactoferrin; $\mathrm{Mn}$ is bound to the milk fat membrane; Co is a key mineral in the large vitamin B12 molecule; Mo is bound to xanthine oxidase, etc. [2]. Milk includes inorganic and organic $\mathrm{Cr}$ in the complex form of $\mathrm{Cr}^{3+}$, which includes nicotinic acid, glutamic acid, glycin, and cysteine [3]. 
Several reported values in the literature for the concentrations of minerals and trace elements in milk show a wide variation due to numerous factors, including stage of lactation, the nature of the soil, season, cattle breed, type of feed, etc. [4, 5]. A study reported that contaminated fodder was responsible for raising heavy metals concentrations in cattle milk in Sudan [6]. Wellknown contaminants include $\mathrm{Fe}, \mathrm{Cu}$, and $\mathrm{Ni}$ caused by dairy equipment that is reused and not replaced by recycling [7, 8]. Alongside these, numerous researchers have recorded elevated levels of $\mathrm{Cd}$ and $\mathrm{Pb}$ in milk in cattle reared close to industries and highways $[9,10]$. It is well recognized that $\mathrm{Pb}$ and $\mathrm{Cd}$ can adversely affect individual health - primarily of children, who are more vulnerable to these metals than adults. $\mathrm{Pb}$ substitutes the chemically identical essential metals like $\mathrm{Fe}, \mathrm{Ca}$, and $\mathrm{Zn}$ from their metabolic sites and disables them to perform their proper functions such as $\mathrm{Pb}$ against $\mathrm{Fe}$ by diminishing the oxygen supply. In the same way, $\mathrm{Pb}$ works against $\mathrm{Ca}$ in neurons and affects their activities. The effects of $\mathrm{Pb}$ toxicity are characterized by low IQ, sluggish growth, anemia, and neurological disorders, etc., in children, while adults can see reproductive complications, hypertension, and renal failure [11]. An epidemic originating in Japan due to $\mathrm{Cd}$ effluence was evident in an ailment known as "itai-itai" a sign of rigorous osteoporosis [12].

The eastern region of Karachi consists of 100 percent urban areas and four towns with a population of nearly 3 million [13]. Primarily, milk is supplied in this district from the dairy farms located in the outskirts of the city. Usually, to stabilize the freshness and raising the volume of milk, adding ice is a routine practice. Moreover, aerial pollutants freely contaminate the milk in open steel or aluminum alloy vats or containers at some shops and may also disturb the metal concentration. In Karachi city, dairy colonies are situated in close proximity to highways or heavy traffic, and industrial areas such as Landhi Cattle Colony (the world's largest) approach the Landhi Industrial Area, Bilal Cattle Colony, and Korangi Industrial Area (KIA), etc. Besides, wastes discharged from the industries contain vast amounts of deleterious chemicals, including heavy metals [14]. These effluents contaminate the hydrosphere and animal feed that increases the heavy metal level of an animal's origin food. A study [15] reported that drinking water from various sources in industrial zones of Karachi was found to be extremely contaminated with $\mathrm{Cr}$ and $\mathrm{Pb}$.

Therefore, the current investigation was conducted to evaluate the quality of milk and assess the physico-chemical properties and heavy metal (essential and non-essential metals) concentrations in milk samples transported from the cattle colonies situated near industrial zones available for residents of District East, and compared the results with the available literature.

\section{Materials and Methods}

Random sampling methods were applied for the collection of milk samples in accordance with the AOAC procedure [16]. Two separate sets of approximately $250 \mathrm{ml}$ of fresh milk samples in plastic pouches were taken from milk vender shops, homes, and from dairy farms of 20 locations of four District East towns, namely Gulshan, Korangi, Landhi, and Shah Faisal at 10-11 a.m. during winter (November to December). A total of 40 samples were kept in iced boxes and transported to the laboratory in good condition. After the examination of physicochemical properties, samples were stored at $-20^{\circ} \mathrm{C}$ until required for metal analysis.

Physico-chemical properties or intrinsic factors are the formulation criteria to estimate purity [17]. In this perspective, physico-chemical properties $(\mathrm{pH}$, conductivity, total dissolved solids, salinity, and dissolved oxygen) and temperature of milk samples were recorded using a calibrated Hach multiparameter (model Sension $\mathrm{TM}^{105}$ ) by direct immersion of the probe in the samples, while the standard method [16] was applied to determine the specific gravity of milk samples.

All chemicals used were analytical AR grade (Merck) throughout the work; concentrated $\mathrm{HNO}_{3}$ (65\%) was used in the highest purity range. Deionized water was used in the whole process. Whattman No. 40 filter papers were used for filtration. To ensure the removal of metal contamination, all glassware was kept in $20 \% \mathrm{HNO}_{3}$ for $48 \mathrm{~h}$, rinsed with deionized water, and dried at $120^{\circ} \mathrm{C}$ in an electric oven. The digested solutions of samples were prepared by treating $10 \mathrm{ml}$ milk samples with $5 \mathrm{ml}$ of concentrated $\mathrm{HNO}_{3}$. The digestion mixture was heated at $105^{\circ} \mathrm{C}$ on a preheated electric hot plate for an hour or until the solution became clear. The residues were removed from the solutions by filtering the solutions through a $100 \mathrm{ml}$ Pyrex flask and the volume made up to the mark with deionized water. A blank was also prepared under identical conditions. Stock solutions of $\mathrm{Cr}, \mathrm{Mn}, \mathrm{Fe}, \mathrm{Co}$, $\mathrm{Ni}, \mathrm{Cu}, \mathrm{Zn}, \mathrm{Cd}$, and $\mathrm{Pb}$ of 1,000 ppm from Merck were used for the preparation of standards by diluting known volumes of these stocks suitable for initial and continued calibration verification. The levels of desired heavy metals were determined through a Perkin Elmer A Analyst 700 Atomic Absorption Spectrophotometer (USA) equipped with a standard burner and air-acetylene supply, while standard hollow cathode lamps of respective metal were used as a radiation source.

For cluster analyses, Ward's linkage strategy was applied with Euclidean distance as the resemblance function to organize data into groups. The correlation structure among variables was sought through principal component analysis (PCA). For all analyses, the multivariate statistical technique that we performed was implemented on Minitab Version 11.

\section{Results and Discussion}

The physico-chemical properties $\mathrm{pH}$, conductivity, salinity, total dissolved solids (TDS), dissolved oxygen (DO), and specific gravity were observed in samples collected from different points of District East and grouped 


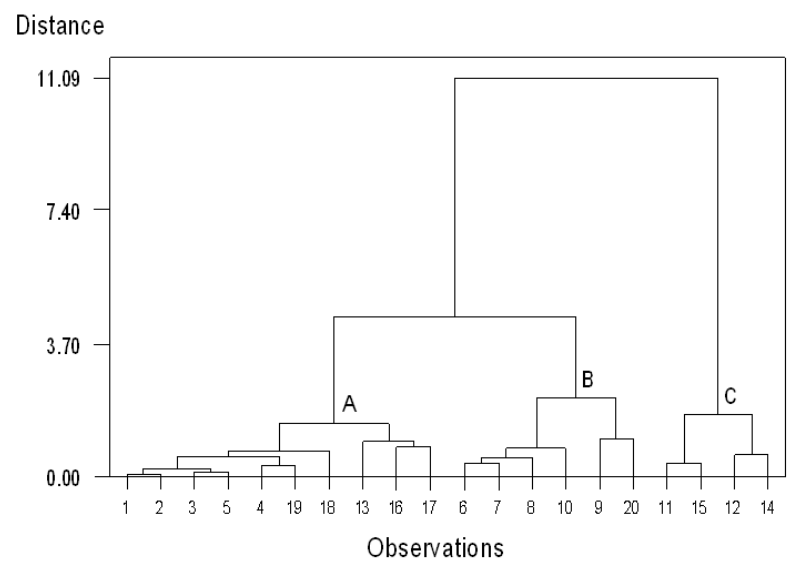

Fig. 1. Dendrogram derived from Ward's cluster analysis of mean values of physico-chemical parameters of milk samples.

as shown in Fig. 1. The representative dendrogram for this study clearly shows three distinct clusters (A, B, and C) with corresponding linkage distances. Cluster A contained observations of samples of 10 locations $(1,2,3,4,5,13$, $16,17,18$, and 19) characterized by higher values of $\mathrm{pH}$, intermediate values of conductivity, salinity, and TDS, and low levels of DO. Cluster B was comprised of profiles of six samples $(6,7,8,9,10$, and 20) and indicated the intermediate values of $\mathrm{pH}$, lower values of conductivity, salinity, and TDS, and higher levels of DO. Finally, Cluster $\mathrm{C}(11,12,14$, and 15$)$ represented low values of $\mathrm{pH}$, and higher values of conductivity, salinity, and TDS, and an intermediate level of DO. However, specific gravity did not show any significant trend.

The $\mathrm{pH}$ of a food product influences both microbial growth and survival, and measures the acidity of a food sample (and often finds the kinds of microbes that grow in it) [18]. While the conductivity of milk is a significant aspect in the identification of various epidemics such as mastitis that manipulate the worth of milk, it is a probable health risk for livestock [19]. Salinity specifies the whole quantity of dissolved salts in watery medium, usually expressed in ppth (o/oo). However, TDS determines the amount of inorganic salts $\left(\mathrm{Ca}, \mathrm{Mg}, \mathrm{K}, \mathrm{Na}, \mathrm{HCO}_{3}{ }^{-}, \mathrm{SO}_{4}{ }^{2}\right.$, and $\mathrm{Cl}^{-}$) and a negligible quantity of organic substances that are dissolved in water. DO reflects to the measurement of dissolved oxygen in aqueous medium $(\mathrm{mg} / \mathrm{l})$ from the atmosphere, and the biological progression that generates

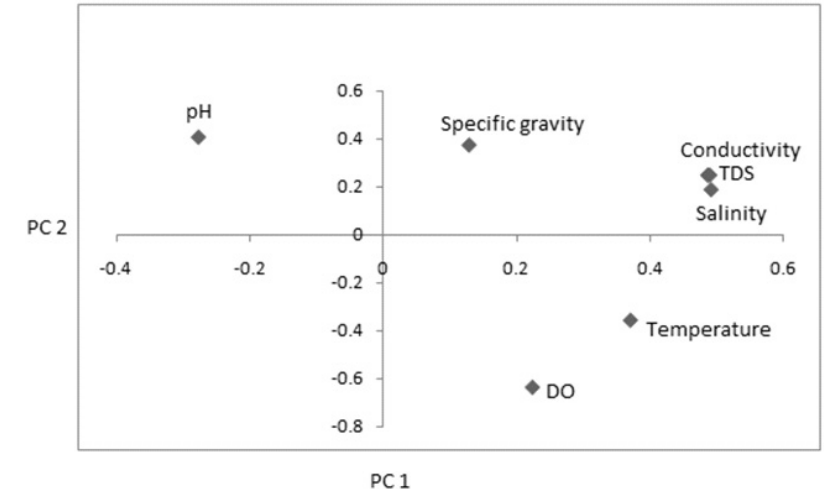

Fig. 2. Results of PCA for the physico-chemical parameters of milk samples.

and uses oxygen [20]. Moreover, concentrations of DO in milk provide a helpful parameter for indirectly estimating freshness and the loss of ascorbic acid [21].

The measured values of $\mathrm{pH}$, conductivity, salinity, TDS, DO, and specific gravity ranged 5.75-6.81, 2.36-5.70 mS/cm, $1.60-3.80$ o/oo, $1.55-3.72 \mathrm{~g} / \mathrm{l}$, $0.28-1.04 \mathrm{mg} / \mathrm{l}$, and $1.017-1.035$ in the same order as depicted in Table 1. Exact 10\% samples showed lower $\mathrm{pH}$ values than the reference lower limit. The lowest values of conductivity, salinity, and TDS (including specific gravity) were measured in sample 9 , whereas conductivity found around two folds below the lower limit of reference and specific gravity slightly less than the reference, but the highest value of these parameters were measured in sample 14. The peak concentration of DO was noted in sample 4 and the lowest in sample 18.

The resultant principal component analysis (PCA) is highlighted in Fig. 2. The cumulative contribution of the first three components accounted for $90 \%$ of the cumulative variance in the data set of physico-chemical parameters of fresh milk samples. The first component, accounting for $51 \%$ of variation, was largely a function of salinity, TDS, and conductivity. The second component $(23 \%)$ is principally controlled by $\mathrm{DO}, \mathrm{pH}$, specific gravity, and temperature. The third component, accounting for $16 \%$ of the total variance, is basically a combination of specific gravity, $\mathrm{pH}$, temperature, and $\mathrm{DO}$.

The detected concentrations of nine heavy metals $(\mathrm{Cr}$, $\mathrm{Mn}, \mathrm{Fe}, \mathrm{Co}, \mathrm{Ni}, \mathrm{Cu}, \mathrm{Zn}, \mathrm{Cd}$, and $\mathrm{Pb}$ ) in fresh milk samples collected from East District were grouped as shown in

Table 1. Ranges of intrinsic factors in groups derived from Dendrograms at temperature range $20.0 \pm 4.0^{\circ} \mathrm{C}$.

\begin{tabular}{|c|c|c|c|c|c|c|}
\hline Group code & $\mathrm{pH}$ & $\begin{array}{c}\text { Conductivity } \\
\mathrm{mS} / \mathrm{cm}\end{array}$ & $\begin{array}{c}\text { Salinity } \\
\text { o/oo }\end{array}$ & $\begin{array}{c}\mathrm{TDS} \\
\mathrm{g} / \mathrm{l}\end{array}$ & $\begin{array}{c}\text { DO } \\
\mathrm{mg} / \mathrm{l}\end{array}$ & Specific gravity \\
\hline $\mathrm{A}$ & $6.52-6.81$ & $3.58-4.30$ & $1.99-2.90$ & $2.24-2.90$ & $0.28-0.92$ & $1.019-1.035$ \\
\hline $\mathrm{B}$ & $5.75-6.70$ & $2.36-3.64$ & $1.60-2.30$ & $1.55-2.25$ & $0.39-1.04$ & $1.017-1.033$ \\
\hline $\mathrm{C}$ & $5.75-6.54$ & $4.87-5.70$ & $3.30-3.80$ & $3.23-3.72$ & $0.63-0.99$ & $1.028-1.033$ \\
\hline Reference & $6.3-6.9^{\mathrm{a}}$ & $4-5^{\mathrm{b}}$ & -- & -- & -- & $1.023-1.040^{\mathrm{c}}$ \\
\hline
\end{tabular}

a: Hui, 1996; ' : Hussain et al., 2012; ": Macrae et al., 1993. 


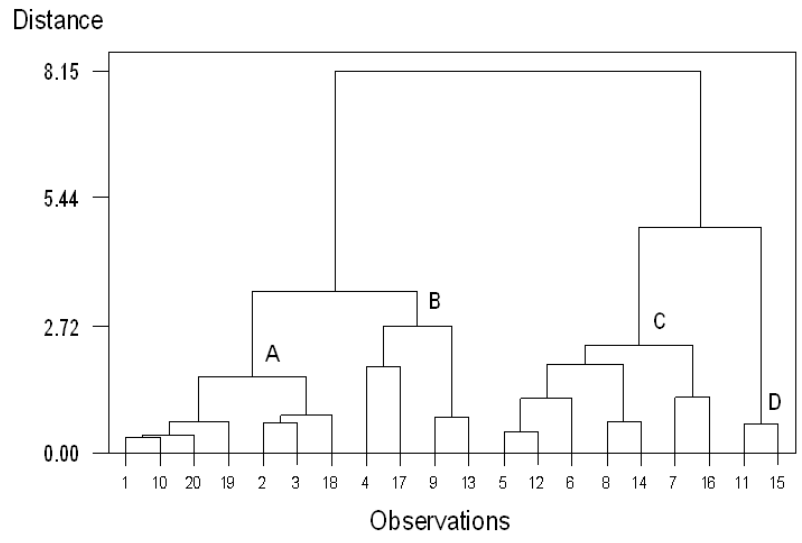

Fig. 3. Dendrogram derived from Ward's cluster analysis of mean concentrations of heavy metals in fresh milk samples $(n=20)$.

Fig. 3. Four distinct clusters (A, B, C, and D) were derived with subsequent relation distances. Group A consisted of samples of point No.7 (1, 2, 3, 10, 18, 19, and 20) characterized by the highest concentrations of four metals $(\mathrm{Cr}$, $\mathrm{Mn}, \mathrm{Co}$, and Ni), intermediate concentrations of four metals $(\mathrm{Cu}, \mathrm{Zn}, \mathrm{Cd}$, and $\mathrm{Pb})$ and the lowest concentration of one metal (Fe). Group B was composed of samples of location No. 4 (4, 9,13 , and 17) recognized by the intermediate concentrations of seven metals $(\mathrm{Cr}, \mathrm{Mn}, \mathrm{Fe}, \mathrm{Co}, \mathrm{Ni}, \mathrm{Cd}$, and $\mathrm{Pb}$ ) and the lowest levels of two metals ( $\mathrm{Cu}$ and $\mathrm{Zn}$ ). However, group $\mathrm{C}$ also contained samples of location No. 7 (5, 6, 7, 8, 12, 14, and 16) and represented the highest levels of four metals $(\mathrm{Cu}, \mathrm{Zn}$, $\mathrm{Cd}$, and $\mathrm{Pb}$ ) and intermediate levels of five metals $(\mathrm{Cr}, \mathrm{Mn}, \mathrm{Fe}$, $\mathrm{Co}$, and Ni). Lastly, group D was recognized as the smallest group, comparatively, and illustrated the highest concentrations of Fe, intermediate concentrations of $\mathrm{Cu}$ and $\mathrm{Zn}$, and the lowest concentrations of six metals $(\mathrm{Cr}, \mathrm{Mn}, \mathrm{Co}, \mathrm{Ni}, \mathrm{Cd}$, and $\mathrm{Pb}$ ).

The ranges of mean concentrations of essential trace elements $(\mathrm{Cr}, \mathrm{Mn}, \mathrm{Fe}, \mathrm{Co}, \mathrm{Ni}, \mathrm{Cu}$, and $\mathrm{Zn}$ ) were assessed as $0.001-0.232 \mathrm{mg} / 1,0.001-0.460 \mathrm{mg} / \mathrm{l}$, 0.001-3.260 mg/1, 0.001-0.108 mg/1, 0.001-0.122 mg/l, $0.001-0.098 \mathrm{mg} / \mathrm{l}$, and $2.086-5.498 \mathrm{mg} / \mathrm{l}$, respectively. Only $5 \%$ of samples showed the least concentration of $\mathrm{Cr}$ and $90 \%$ of samples were exposed to the higher level in contrast to the reference level according to Table 2. The highest level was estimated at 13 to 14 folds above the reference. However, its chronic toxicity is characterized by renal and hepatic damage as well as circulatory and nerve tissue troubles [22].

For Mn, 35\% of samples showed the minimum level and the highest level was found 17 to 18 times more than the reference value as shown in Table 2 . However, $50 \%$ of samples exhibited higher values than reference. A common source responsible for increased Mn levels in milk is fodder, particularly whole grain fodder [23]. Mn toxicity can occur in individuals with liver failure characterized by Mn accumulation within the liver and other organs such as the brain; the latter results in neurological abnormalities $[24,25]$. The average values of $\mathrm{Cr}$ and $\mathrm{Mn}$ concentrations were found to be higher than the reference but did not exceed the total daily intake of $\mathrm{Cr}(0.24 \mathrm{mg})$ and lower limit of latest safe and adequate daily dietary intakes of $\mathrm{Mn}$ (2.3 mg for men and $1.8 \mathrm{mg}$ for women) as established by the U.S. Food and Nutrition Board [26].

For Fe, the lowest level was exhibited by only a $5 \%$ sample, while the highest concentration was found to be 15- to 16-fold greater than the reference, as mentioned in Table 2. Furthermore, $90 \%$ of assessments exhibited above the reference. The plausible increased levels of $\mathrm{Fe}, \mathrm{Co}$, and $\mathrm{Cu}$ in milk samples are the results of utensils employed for milking, which are normally finished steel and aluminum alloys and are not recycled until leakage is found.

Only $5 \%$ of samples showed a minimum level of Co, whereas the maximum level was assessed as far above the reference level (Table 2), although it is well recognized that $\mathrm{Co}$ and Co compounds can be carcinogenic if available in ionic form [27].

Most of the samples (55\%) showed low levels of $\mathrm{Ni}$ while the highest value was found three to four times more than the reference level as described in Table 2. Likewise, $20 \%$ of samples were estimated as above reference but less than the tolerable upper intake level for adults $(1.0 \mathrm{mg} / \mathrm{d})$. A nearly similar level of Ni $\left(0.010-0.131 \mathrm{mg} \mathrm{L}^{-1}\right)$ in bovine milk samples were obtained from Mumbai, India [8]. Ni plays an adversary function against 13 important metal ions by means of substitution of their bioactive sites [28].

The minimum level of $\mathrm{Cu}$ was measured in $20 \%$ of samples, although the highest level was determined to be approximately two times higher than the reference value as depicted in Table 2 . Nevertheless, only $15 \%$ of results were found greater than the reference. Another significant

Table 2. Ranges of concentrations ( $\mathrm{mg} / \mathrm{l})$ of heavy metals in groups derived from Dendrogram.

\begin{tabular}{|c|c|c|c|c|c|c|c|c|c|}
\hline Group & $\mathrm{Cr}$ & $\mathrm{Mn}$ & $\mathrm{Fe}$ & $\mathrm{Co}$ & $\mathrm{Ni}$ & $\mathrm{Cu}$ & $\mathrm{Zn}$ & $\mathrm{Cd}$ & $\mathrm{Pb}$ \\
\hline $\mathrm{A}$ & $0.002-0.232$ & $0.001-0.460$ & $0.090-0.926$ & $0.001-0.108$ & $0.001-0.122$ & $0.001-0.044$ & $2.950-4.020$ & $0.001-0.032$ & $0.001-0.412$ \\
\hline $\mathrm{B}$ & $0.046-0.202$ & $0.001-0.396$ & $0.001-0.083$ & $0.001-0.034$ & $0.001-0.010$ & $0.001-0.025$ & $2.086-2.720$ & $0.001-0.042$ & $0.001-0.295$ \\
\hline $\mathrm{C}$ & $0.028-0.174$ & $0.001-0.384$ & $0.658-2.100$ & $0.002-0.054$ & $0.000-0.062$ & $0.004-1.688$ & $3.830-5.498$ & $0.000-0.053$ & $0.000-1.428$ \\
\hline $\mathrm{D}$ & $0.001-0.098$ & $0.001-0.002$ & $3.163-3.260$ & $0.018-0.032$ & 0.001 & $0.030-0.070$ & $3.890-4.462$ & $0.001-0.028$ & $0.154-0.170$ \\
\hline $\begin{array}{c}\text { Refe- } \\
\text { rence* }\end{array}$ & 0.017 & 0.026 & 0.210 & 0.0005 & 0.025 & 0.052 & 4.200 & -- & -- \\
\hline
\end{tabular}

*: Renner et al., 1989. 
$\mathrm{Cu}$ contamination source of milk occurs through higher levels of water and feed ingested by cattle [8].

The least level of $\mathrm{Zn}$ was observed in only $5 \%$ of samples, although the maximum concentration was observed in contrast to reference level (Table 2). The majority of samples $(70 \%)$ possessed lower levels of $\mathrm{Zn}$ than the reference value, even though $\mathrm{Zn}$ insufficiency can result in a variety of medical disorders based on age, growing period, and associated metals deficit. Zn deficiency was found by Prasad to manifest itself in teenagers through developmental issues and late sexual maturation [29].

The levels of non-essential (potentially toxic) trace elements of $\mathrm{Cd}$ and $\mathrm{Pb}$ were assessed in the ranges of $0.001-0.053 \mathrm{mg} / 1$ and $0.001-1.428 \mathrm{mg} / 1$, respectively. Although the lowest levels of Cd were assessed in 35\% of samples, the highest were measured five to six times above the tolerable limit of $0.010 \mathrm{ppm}$ as established by [30]. A greater percentage $(65 \%)$ of the samples was found to be more contaminated by $\mathrm{Cd}$ than the tolerable limit. Cadmium contamination occurred by a polluted environment via burning plastic smoke and chemical additives like pigments or stabilizers [31].

Twenty percent of samples showed the lowest levels of $\mathrm{Pb}$, whereas the highest level was noted far above the maximum level of $0.02 \mathrm{mg} / \mathrm{l}$ established by European Commission Regulation No. 1881/2006 [32]. The majority $(75 \%)$ of samples showed $\mathrm{Pb}$ contamination above tolerable limits, whereas milk, fasting, low levels of calcium, vitamin $\mathrm{D}$, and iron have been shown to increase $\mathrm{Pb}$ absorption in laboratory animals [33].

The results of principal component analysis (PCA) report are given Fig. 4. Together, the first four components accounted for $71 \%$ of the cumulative variance in the data set of heavy metal levels in fresh milk collected from District East. The first component, accounting for 22\%, had higher loadings for $\mathrm{Cd}, \mathrm{Co}, \mathrm{Fe}$, and $\mathrm{Cr}$. The second component $(20 \%)$ was associated with $\mathrm{Cr}, \mathrm{Mn}, \mathrm{Ni}$, and Co. The third component accounted for $15 \%$ of the total variance as chiefly a grouping of $\mathrm{Zn}, \mathrm{Cu}, \mathrm{Ni}$, and $\mathrm{Co}$. The fourth component (14\%) exhibited the higher loadings for $\mathrm{Pb}, \mathrm{Cu}, \mathrm{Cd}$, and $\mathrm{Co}$.

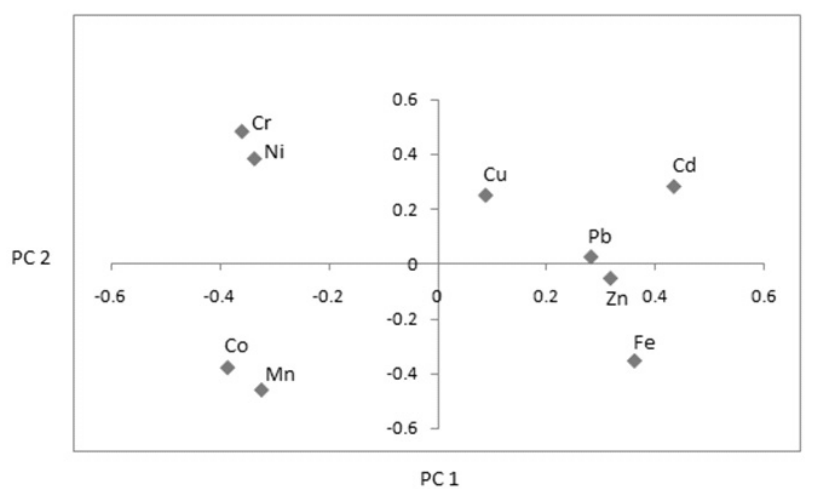

Fig. 4. Results of PCA for concentrations of heavy metals in fresh milk samples.
Numerous investigations have reported high levels of heavy metals in bovine milk linked chiefly to anthropogenic factors. Recently, the levels of heavy metals in a variety of powder and liquid milk samples gathered from local markets of Peshawar were measured for $\mathrm{Cr}, \mathrm{Mn}, \mathrm{Fe}$, $\mathrm{Ni}, \mathrm{Cu}, \mathrm{Zn}, \mathrm{Cd}$, and $\mathrm{Pb}$ in the range of $0.0001-0.0003$ ppm, 0.01-0.04 ppm, 0.02-0.43 ppm, 0.003-0.009 ppm, 0.12-0.17 ppm, 0.69-5.01 ppm, 0.01-0.25 ppm, and 0.0001-0.015 ppm respectively [34]. Another study reported high levels of $\mathrm{Cr}\left(3.750-8.400 \mathrm{mg} \mathrm{L}^{-1}\right), \mathrm{Cu}$ (0.500-1.354 $\left.\mathrm{mg} \mathrm{L}^{-1}\right), \mathrm{Cd}\left(0.092-0.250 \mathrm{mg} \mathrm{L}^{-1}\right)$, and $\mathrm{Pb}$ $\left(0.455-2.000 \mathrm{mg} \mathrm{L}^{-1}\right)$ in bovine milk samples collected from various locations in Jhang, Pakistan [35]. A significant higher level was recorded in Spanish cow's milk samples collected from the vicinities of great industrial and mining activities [36]. An investigation exposed remarkably high levels of Fe (10.95-16.38 $\mu \mathrm{g} / \mathrm{g}), \mathrm{Cu}(0.623-2.836 \mu \mathrm{g} / \mathrm{g})$, $\mathrm{Zn}(4.770-10.75 \mu \mathrm{g} / \mathrm{g}), \mathrm{Cd}(0.200-0.288 \mu \mathrm{g} / \mathrm{g})$, and $\mathrm{Pb}$ $(1.850-4.404 \mu \mathrm{g} / \mathrm{g})$ in cow's milk samples compiled from five location of Egypt's El-Qalyubia Governorate [37]. Significantly higher levels of 1.134-1.265 mg/l Cr, 21.266-3.522 mg/l Ni, 0.171- $0.122 \mathrm{mg} / \mathrm{l} \mathrm{Cd}$, and 23.240-16.704 mg/1 Pb were recorded in milk samples of cattle reared close to sewage drains in Faisalabad, Pakistan [9]. Noticeable differences were found in concentrations of Cr (17.566 mg/l), Mn (1.788 mg/l), Fe (50.873 mg/l), $\mathrm{Ni}(30.132 \mathrm{mg} / \mathrm{l}), \mathrm{Cu}(2.520 \mathrm{mg} / \mathrm{l}), \mathrm{Zn}(32.387 \mathrm{mg} / \mathrm{l}), \mathrm{Cd}$ $(1.631 \mathrm{mg} / \mathrm{l})$, and $\mathrm{Pb}(5.501 \mathrm{mg} / \mathrm{l})$ in cattle milk samples of industrial areas Kano, and $\mathrm{Cr}(1.568 \mathrm{mg} / \mathrm{l}), \mathrm{Mn}$ (0.219 mg/l), Fe (3.238 mg/l), Ni (2.097 mg/l), Cu (0.214 mg/l), Zn (5.521 mg/l), Cd (0.099 mg/l), and Pb $(0.710 \mathrm{mg} / \mathrm{l})$ in the relatively non-industrial zone of Zaria, Nigeria [10].

\section{Conclusion}

Nearly all samples showed the values of $\mathrm{pH}$ and specific gravity within the reference limit that proved their freshness and purity. However, the majority of samples revealed the magnitude of conductivity below the range of reference. The majority of the samples possessed higher levels of essential metals $(\mathrm{Cr}, \mathrm{Mn}, \mathrm{Co}$, and $\mathrm{Cu}$ ) while concentrations of $\mathrm{Zn}$ and $\mathrm{Ni}$ were recorded at a lower level in contrast to reference values. However, elevated levels of non-essential potentially toxic trace elements $\mathrm{Pb}$ and $\mathrm{Cd}$ were detected in a significant number of samples.

In light of the results, we concluded that the remarkably higher levels of essential and non-essential trace elements might be connected with contaminated animal drinking water, industrial and sewage sludge-irrigated water, vegetation and animal feed, and heavy vehicle loads.

\section{References}

1. TFS (Toxicology Factsheet Series). Mercury, Lead, Cadmium, Tin and Arsenic in Food. Food Safety Authority of Ireland, 1, 13, 2009. 
2. FENNEMA O.R. Food Chemistry. $3^{\text {rd }}$ Ed. Owen R. Fennema, Chapter no. 14, 1996.

3. HAZELL T. World Review Nutrition Diet. 46, 1, 1985.

4. PERWEEN R. Review: Factors involving in fluctuation of trace metals concentrations in bovine milk. Pak. J. Pharm. Sci., 28 (3), 1033, 2015.

5. PILARCZYK R., WÓJCIK J., CZERNIAK P., SABLIK P., PILARCZYK B., TOMZA-MARCINIAKA. Concentrations of toxic heavy metals and trace elements in raw milk of Simmental and Holstein-Friesian cows from organic farm. Environ Monit Assess, Springer, DOI 10.1007/s10661-0133180-9, 2013.

6. ABDALLA M.O.M, HASSABO A.A., ELSHEIKH N.A.H. Assessment of some heavy metals in waste water and milk of animals grazed around sugar cane plants in Sudan. Livestock Research for Rural Development. 25, Article \#212, 2013.

7. MAAS S., LUCOT E., GIMBERT F., CRINI N., BADOT P. Trace metals in raw cows' milk and assessment of transfer to Comté cheese. Food Chem. 129, (1), 7, 2011.

8. ZODAPE G.V., DHAWAN V.L., WAGH, R.R. Assessment of level of Metals in Cow milk collected from different location in and around Mumbai City, India. Bionano Frontier, 6, 126, 2013.

9. ASLAM B., JAVED I., KHAN F.H., REHMAN Z. Uptake of Heavy Metal Residues from Sewerage Sludge in the Milk of Goat and Cattle during Summer Season. Pak. Vet. J. 31 (1), 75, 2011.

10. OGABIELA E.E., UDIBA U.U., ADESINA O.B., HAMMUEL C., ADE-AJAYI F.A., YEBPELLA G.G., MMEREOLE U.J., ABDULLAHI M. Assessment of Metal Levels in Fresh Milk from Cows Grazed around Challawa Industrial Estate of Kano, Nigeria. J. Basic and App. Scientific Res. 1 (7), 533, 2011.

11. WHITNEY E., ROLFES S.R. Understanding Nutrition. $10^{\text {th }}$ Ed., Thompson Wadsworth Australia, 458, 2005.

12. OCHIAI E. Chemicals for Life and Living, Springer-Verlag Berlin Heidelberg, 186, 260, 2011.

13. PWD (Population Welfare Department), Government of Sindh. Population Size and Growth of District Karachi East, West, South and Malir. http://www.pwdsindh.Gov.Pk., 2014.

14. NAGA W.M.A., ALLAM S.M. Trace metals concentration in the tissues of Tilapi Zillii Gerv. Exposed to waste water discharge of an Egyptian copper works. Pak. J. Marine Sci., 8 (2), 115, 1999.

15. UL-HAQ N., ARAIN M.A., HAQUE Z., BADAR N., MUGHAL N. Drinking water contamination by chromium and lead in industrial lands of Karachi. J. Pak. Med. Assoc., 59 (5), 270, 2009.

16. AOAC (Association of Official Analytical Chemists). Official Methods of Analysis International. 17 ${ }^{\text {th }}$ Ed. Washington, DC: AOAC, 2000.

17. BRENNAN J.G., GRANDISON A.S. Food Processing Handbook. $2^{\text {nd }}$ Ed., Wiley-VCH Verlag and Co. KGaA, Boschstr, Weinheim, Germany, 2, 494, 2012.

18. OYARZABAL O.A., BACKERT S. Food Science Text Series: Microbial Food Safety an Introduction. Springer Science+Business Media, 40, 2012.

19. PYÖRÄLÄ S. Indicators of inflammation in the diagnosis of mastitis. A Journal on Animal Infection, Vet. Res., 34 (5), $565,2003$.

20. HANRAHAN G. Key Concept in Environmental Chemistry. Academic Press, Elsevier, 135, 2012.
21. RENNER E., SCHAAFSMA G., SCOTT K. J. Micronutrients in milk. In: Micronutrients in milk and milk-based food products, Renner E. (eds), Elsevier Science Publishers LTD, England, 1-70, 1989.

22. LENNTECH. Water Treatment and Purification. Lenntech, Rotterdamseweg, Netherland, 2004.

23. GROPPER S.S., SMITH J.L., GROFF J.L. Advanced Nutrition and Human Metabolism. Thomson Wadsworth, $4^{\text {th }}$ Ed. Chapter 12, 2005.

24. HAUSER R.A., ZESIEWICZ T.A., ROSEMURGY A.S., MARTINEZ C., OLANOW C.W. Manganese intoxication and chronic liver failure. Ann. Neurol., 36 871, 1994.

25. REYNOLDS A.P., KIELY E., MEADOWS N. Manganese in long term paediatric parenteral nutrition. Archives of Disease in Childhood, 71 (6), 527, 1994.

26. Food and Nutrition Board, Institute of Medicine. Manganese: Dietary reference intakes for vitamin A, vitamin $\mathrm{K}$, boron, chromium, copper, iodine, iron, manganese, molybdenum, nickel, silicon, vanadium, and zinc. Washington, D.C.: National Academy Press; 394-419, 2001.

27. GREIM H., SNYDER R. Toxicology and Risk Assessment: A Comprehensive Introduction. John Wiley \& Sons, Ltd., USA, chapter $\mathbf{6}, \mathbf{2 0 0 8}$

28. TALLKVIST J., WING A., TJALVE H. Enhanced intestinal nickel absorption in iron-deficient rats. Pharmacology and Toxicology, 75, 244, 1994.

29. PRASAD A.S. Clinical, biochemical and nutritional spectrum of zinc deficiency in human subjects: An update. Nutr. Rev. 41, 197, 1983.

30. NOVINE N. Regulation of allowed pesticides, toxins, mycotoxins, metals and histamine and similar substances in food. Narodne Novine 46, 1583, 1994.

31. SOARES V.A., KUS M.M.M., PEIXOTO A.L.C., CARROCCI J.S., SALAZAR R.F.S., FILHO H.J.I. Determination of nutritional and toxic elements in pasteurized bovine milk from Vale do Paraiba region (Brazil). Food Control, 21, 45, 2010.

32. EC (Commission regulation) no. 1881/2006 of 19 December 2006 setting maximum levels for certain contaminants in foodstuffs. Official Journal of the European Union, L 364, $5,2006$.

33. MUDGAL V., MADAAN N., MUDGAL A., SINGH R.B., MISHRA S. Effect of Toxic Metals on Human Health. The Open Nutraceutical J., 3, 94, 2010.

34. LUTFULLAH G., KHAN A.A., AMJAD A.Y., PERVEEN S. Research Article Comparative Study of Heavy Metals in Dried and Fluid Milk in Peshawar by Atomic Absorption Spectrophotometry. The Sc. W. J., Hindawi Publishing Corporation; Volume 2014, Article ID 715845, 5, 2014.

35. YOUNUS M., ABBAS T., RAFIQUE K., SAJID M., ASLAM M., ZAFAR M. Analyses of selected heavy metals and aflatoxin F1 in milk for human consumption in Jhang city, Pakistan. International food policy research institute (IFPRI), Washington DC, USA, 2013.

36. GONZÁLEZ-MONTAÑA, J.R., SENÍS, E., GUTIÉRREZ, A., PRIETO F. Cadmium and lead in bovine milk in the mining area of the Caudal River (Spain). Environ. Mon. Ass. 184 (7), 4029, 2012.

37. MALHAT F., HAGAG M., SABER A., FAYZ A.E. Contamination of Cows Milk by Heavy Metal in Egypt. Bull. Environ. Contam. Toxicol., 88, 611, 2012. 